\title{
The paradigm of non-radiographic sacroiliitis-why the ongoing doubts?
}

\author{
Walter P. Maksymowych ${ }^{1,2}$ (i) \\ Received: 19 November 2020 / Revised: 24 November 2020 / Accepted: 25 November 2020 / Published online: 6 January 2021 \\ (C) International League of Associations for Rheumatology (ILAR) 2021
}

The concept of non-radiographic axial spondyloarthritis (nr$\operatorname{axSpA}$ ) gained prominence from the understanding that definite plain radiographic features of sacroiliitis evolve over many years, and diagnosis is often delayed, while treatment is particularly effective in the early stages of disease. Many patients presenting with features suggestive of SpA but without radiographic sacroiliitis were indiscriminately labeled as "undifferentiated SpA" but then denied highly effective tumor necrosis factor inhibitor (TNFi) therapies because the drug label confined treatment to those with radiographic sacroiliitis. It became necessary to capture these patients with early disease in new classification criteria that would include patients within a broader spectrum of axSpA, which became possible with the advent of MRI for early detection of sacroiliitis. This was accomplished using a two-pronged approach in the 2009 Assessments in SpondyloArthritis international Society (ASAS) classification criteria [1]: (1) An imaging arm allows patients to be classified as having axSpA if they have MRI evidence of sacroiliitis and at least one SpA feature. (2) A clinical arm permits classification of axSpA in the absence of MRI inflammation if the patient is positive for HLA B27 and has at least two SpA features. A positive MRI for the purposes of classification was defined by a 2009 consensus of ASAS experts as bone marrow edema (BME) on fat-suppressed scans or osteitis on T1-weighted contrast-enhanced scans in a typical subchondral location [2]. This definition required the presence of at least two BME lesions on a single semicoronal slice through the SIJ or a single lesion on two consecutive slices. The lesion also had to be considered "highly suggestive" of axSpA although what characteristics of the lesion would define it as "highly suggestive" were not elaborated. A 2016

Walter P. Maksymowych

walter.maksymowych@ualberta.ca

1 Department of Medicine, 568 Heritage Medical Research Building, University of Alberta, Edmonton, Alberta T6R 2G8, Canada

2 CARE Arthritis, Edmonton, Canada consensus update of the 2009 ASAS definition further elaborated that the concomitant presence of structural lesions, especially erosion, could help determine whether the BME lesion was "highly suggestive" of axSpA [3].

Soon after publication of the criteria, several studies examined the characteristics of patients classified as nr-axSpA and demonstrated more females and a lower prevalence of HLAB27 as compared to studies that had classified patients using the modified New York criteria [4-6]. This led some to question the accuracy of the criteria, especially the clinical arm, by referencing studies which demonstrated that patients fulfilling only the clinical arm did not demonstrate progression to radiographic sacroiliitis and did not respond to TNFi in placebocontrolled randomized controlled trials (RCT) unless objective features of inflammation in the form of an elevated $\mathrm{C}$ reactive protein (CRP) or MRI inflammation were evident [6, 7]. Proponents of the criteria pointed to the observation that the clinical arm had similar predictive validity to the imaging arm for rheumatologist follow-up diagnosis of axSpA in the ASAS classification cohort [8]. In addition, patients fulfilling the "clinical arm" in the ASAS classification cohort actually had a mean of 3.4 SpA features and meta-analyses of international cohorts demonstrated similar sensitivity/specificity performance of the clinical and imaging arms for rheumatologist diagnosis of axSpA [9].

The authors of the review entitled "Understanding the Paradigm of Non-Radiographic Axial Spondyloarthritis (Benavent and Navarro-Compán)" [10] fall firmly into the camp of the proponents in arguing that the data supports the view that $n r-a x S p A$ resembles radiographic-axSpA (r-axSpA) in terms of the clinical manifestations, disease burden, and treatment response. Certainly, it is now undeniable that patient self-reported symptomatology and impact on quality of life are comparable between these two categories. In comparing patient characteristics and manifestations of disease, it is important to clarify that the diagnosis of axSpA is challenging in its early stages and disease manifestations may vary according to the duration of disease. Consequently, even though the 
purpose of classification criteria is to select patients with homogeneous clinical characteristics across different cohorts, some differences between published cohorts might still be expected for frequency of HLA-B27 and certain clinical manifestations that appear with increasing duration and/or severity of disease as well as factors such as patterns of referral to the rheumatologist and inclusion criteria for the cohort. Benavent and Navarro-Compán provide evidence in their review of the literature that disease characteristics do indeed appear to be similar among different cohorts and between r-axSpA and nraxSpA when the ASAS classification criteria are applied with the exception of a consistently higher percentage of females and a lower frequency of acute anterior uveitis (AAU) in nraxSpA. The latter is to be expected as the frequency of patients with AAU increases with disease duration [11]. A higher percentage of women with nr-axSpA is consistent with data demonstrating lower severity of disease in this gender [12]. Consequently, it can indeed be argued that this data is consistent with nr-axSpA and r-axSpA being part of the spectrum of a single disease entity that is embraced by the ASAS criteria. However, assessment of treatment responses, and especially data from recent RCTs of interleukin-17 targeted therapies in nr-axSpA do indeed raise potential concerns as to the capacity of the criteria to capture a homogeneous disease entity under the category of nr-axSpA.

The recently reported trials of secukinumab $150 \mathrm{mg}$ in axSpA reported differences in ASAS40 responses at week 16 between active drug and placebo that were $29 \%$ and 25\% for r-axSpA (MEASURE-1 and 2, respectively) and $12 \%$ for nr-axSpA $[13,14]$. For the ixekizumab trials, differences in ASAS40 responses at week 16 between active drug and placebo were $30 \%$ for $\mathrm{r}$-axSpA and $16 \%$ for nr-axSpA $[15,16]$. A similarly lower ASAS40 response was noted in patients receiving etanercept in the trial of nr-axSpA as compared to the trial of patients with ankylosing spondylitis [17, 18]. Moreover, the RCT of adalimumab in nr-axSpA demonstrated treatment group differences in ASAS responses only in patients with elevated CRP or the presence of MRI inflammation [6] and all subsequent trials of TNFi therapies have recruited patients with objective evidence of active disease rather than just a high level of symptoms despite use of non-steroidal anti-inflammatory drugs. A propensity-matched analysis of patients with nr-axSpA from the DESIR cohort did not demonstrate a significantly higher ASAS40 response in patients receiving TNFi as compared to usual care in those patients who only met the clinical arm of the criteria [19]. Additional observational cohort data has reported lower responses to TNFi agents in women as compared to men [20]. These data with TNFi agents in nr-axSpA contrast with placebo-controlled trial data in early axSpA conducted prior to the publication of the ASAS criteria where patients with short symptom duration, B27 positivity, and MRI inflammation, demonstrated substantially higher responses to TNFi than those observed in phase III trials of TNFi agents in patients with ankylosing spondylitis $[21,22]$. It could therefore be argued that patients recruited to trials of TNFi and IL17-targeted therapies in nr-axSpA should have demonstrated even higher responses than those observed in phase III trials of $\mathrm{r}$ axSpA since we would expect early axSpA to respond better than established, long-standing axSpA. If the paradigm of axSpA being a continuum of disease from nraxSpA to $\mathrm{r}$-axSpA is correct, we should expect to observe higher responses in $\mathrm{nr}$-axSpA, especially in those patients selected for RCTs because these require objective evidence of inflammation and this has been shown to further enhance responses to bio-DMARDs [23]. Why was this not observed?

An obvious concern relevant to this question is the ASAS definition of a positive MRI. The application of this definition has identified false positive BME in $20-40 \%$ of healthy individuals and those with non-specific spinal disorders [24-26]. The selection of patients for an RCT of axSpA begins with an accurate diagnosis incorporating clinical, lab, and imaging data. Is it possible that clinicians are incentivized to recruit patients for an RCT once some BME meeting the quantitative aspect of the ASAS definition is evident on MRI? After all, the imaging arm requires only a single clinical SpA feature and once this is met, the patient meets trial inclusion criteria for both disease classification and active nr-axSpA. The patient may in fact have pain from a concomitant degenerating disc, could have inflammatory-type back pain as $40 \%$ of such patients meet criteria for inflammatory back pain [27], and could have tried and failed several NSAIDs, and the BASDAI score could be $>4$. Such a patient is now eligible for participation in a trial of nr-axSpA. This example serves to highlight the potential for classification criteria to be misused for diagnostic and other purposes.

In conclusion, the trial data in $\mathrm{nr}-\mathrm{axSpA}$ continues to seed doubts as to the robustness of the criteria and whether they might additionally include patients whose symptoms of back pain are related to mechanical spinal and/or pain-sensitization disorders and not a consequence of axSpA. While the 2009 criteria clearly represent a step in the right direction towards inclusion of patients with early axSpA, we now see that it seems likely that aspects of the criteria, especially how we define a positive MRI, require greater stringency.

\section{Compliance with ethical standards}

Competing interests WPM is the Chief Medical Officer of CARE Arthritis Limited; has acted as a paid consultant/participated in advisory boards for AbbVie, Boehringer Ingelheim, Celgene, Eli Lilly, Galapagos, Janssen, Novartis, Pfizer, and UCB; received research and/or educational grants from AbbVie, Novartis, Pfizer, and UCB; and received speaker fees from AbbVie, Janssen, Novartis, Pfizer, and UCB. 


\section{References}

1. Rudwaleit M, van der Heijde D, Landewé R, Listing J, Akkoc N, Brandt J et al (2009) The development of Assessment of SpondyloArthritis international Society (ASAS) classification criteria for axial spondyloarthritis (Part II): validation and final selection. Ann Rheum Dis 68:777-783

2. Rudwaleit M, Jurik AG, Hermann KG, Landewé R, van der Heijde D, Baraliakos X et al (2009) Defining active sacroiliitis on magnetic resonance imaging (MRI) for classification of axial spondyloarthritis: a consensual approach by the ASAS/OMERACT MRI group. Ann Rheum Dis 68:1520-1527

3. Lambert RGW, Bakker PAC, van der Heijde D, Weber U, Rudwaleit M, Hermann KG et al (2016) Defining active sacroiliitis on MRI for classification of axial spondyloarthritis: update by the ASAS MRI working group. Ann Rheum Dis 75:1958-1963

4. Poddubnyy D, Rudwaleit M, Haibel H, Listing J, Marker-Hermann E, Zeidler H, Braun J, Sieper J (2011) Rates and predictors of radiographic sacroiliitis progression over 2 years in patients with axial spondyloarthritis. Ann Rheum Dis 70:1369-1374

5. Kiltz U, Baraliakos X, Karakostas P, Igelmann M, Kalthoff L, Clink $C$ et al (2012) Do patients with non-radiographic axial spondylarthritis differ from patients with ankylosing spondylitis? Arthritis Care Res 64:1415-1422

6. Sieper J, van der Heijde D, Dougados M, Mease PJ, Maksymowych WP, Brown MA, Arora V, Pangan AL (2013) Efficacy and safety of adalimumab in patients with mon-radiographic axial spondyloarthritis: results of a randomised, placebo-controlled trial (ABILITY-1). Ann Rheum Dis 72:815-822

7. Dougados M, Sepriano A, Molto A, van Lunteren M, Ramiro S, de Hooge M, van den Berg R, Navarro Compan V, Demattei C, Landewé R, van der Heijde D (2017) Sacroiliac radiographic progression in recent onset axial spondyloarthritis: the 5-year data of the DESIR cohort. Ann Rheum Dis 76:1823-1828

8. Sepriano A, Landewé R, van der Heijde D, Sieper J, Akkoc N, Brandt J et al (2016) Predictive validity of the ASAS classification criteria for axial and peripheral spondyloarthritis after follow-up in the ASAS cohort: a final analysis. Ann Rheum Dis 75:1034-1042

9. Sepriano A, Rubio R, Ramiro S, Landewé R, van der Heijde D (2017) Performance of the ASAS classification criteria for axial and peripheral spondyloarthritis: a systematic literature review and meta-analysis. Ann Rheum Dis 76:886-890

10. Benavent D, Navarro-Compán V (2020) Understanding the paradigm of non-radiographic axial spondyloarthritis. Clin Rheumatol. https://doi.org/10.1007/s10067-020-05423-7

11. Varkas G, Vastesaeger N, Cypers H, Colman R, Renson T, Van Praet E et al (2018) Association of inflammatory bowel disease and acute anterior uveitis, but not psoriasis, with disease duration in patients with axial spondyloarthritis. Arthritis Rheumatol 70: $1588-1596$

12. Rusman T, van Vollenhoven RF, van der Horst-Bruinsma IE (2018) Gender differences in axial spondyloarthritis: women are not so lucky. Curr Rheumatol Rep 20:35-47

13. Baeten D, Sieper J, Braun J, Baraliakos X, Dougados M, Emery P, Deodhar A, Porter B, Martin R, Andersson M, Mpofu S, Richards HB, MEASURE 1 Study Group, MEASURE 2 Study Group (2015) Secukinumab, an interleukin-17A inhibitor, in ankylosing spondylitis. N Engl J Med 373:2534-2548

14. Deodhar A, Blanco R, Dokoupilová E, Hall S, Kameda H, Kivitz AJ et al Secukinumab improves signs and symptoms of nonradiographic axial spondyloarthritis: primary results of a randomized controlled phase III study. Arthritis Rheumatol First published August 7 2020. https://doi.org/10.1002/art.41477
15. van der Heijde D, Cheng-Chung Wei J, Dougados M, Mease P, Deodhar A, Maksymowych WP, van den Bosch F, Sieper J, Tomita T, Landewé R, Zhao F, Krishnan E, Adams DH, Pangallo B, Carlier H, COAST-V study group (2018) Ixekizumab, an interleukin-17A antagonist in the treatment of ankylosing spondylitis or radiographic axial spondyloarthritis in patients previously untreated with biological disease-modifying anti-rheumatic drugs (COAST-V): 16 week results of a phase 3 randomised, double-blind, activecontrolled and placebo-controlled trial. Lancet. 392:2441-2451

16. Deodhar A, van der Heijde D, Gensler LS, Kim TH, Maksymowych WP, Østergaard M, Poddubnyy D, Marzo-Ortega H, Bessette L, Tomita T, Leung A, Hojnik M, Gallo G, Li X, Adams D, Carlier H, Sieper J, Morin F, Rahman P, Ariel F, Berman A, Carrio J, Lucero E, Cocco JM, Hidalgo RP, Velasco J, Viola DO, Grisar J, Resch H, Scheinecker C, Melazzi AC, Roimicher L, Scotton AS, Rodriguez AAB, Molina FFC, Barragan SD, Skinner CM, Tena CFP, Remus CRR, Rodriguez JCR, Hong SJ, Kang SW, Lee CK, Lee EB, Lee SH, Park MC, Lee SH, Dokoupilova E, Dvorak Z, Malcova M, Pvelka K, Eklund KK, Jarvinen P, Karjalainen A, Paimela L, Taniguchi Y, Tsuda T, Tada K, Dobashi H, Inui K, Ueki Y, Matsumoto Y, Hatta K, Atsumi T, Goto H, Honjo S, Matsui K, Takakubo Y, Neeck G, Wagner S, Braun J, Blicharshi T, Dudek A, Hrycai P, Plebanski R, Drabiszcak-Piatkowska J, Brzezicki J, Krogulec M, OprisBelinski D, Ramazan AM, Tronaru L, van de Sande MG, Matsievskaya G, Schmidt E, Stanislav M, Yakushin S, Ershova O, Rebroy A, Churchill MA, Flint KP, Greenwald M, Howell MP, Kaine JL, Kivitz A, Klein SJ, Mueller EC, Peters EA, Querubin R, Sayers ME, Scoville CD, Shanahan JC, Roseff R, Hull JE, Mallepalli JR, Sebai MB, Kimmel SC, Goddard DH, Mease PJ, Harris MD, Mabaquiao AR, Diegel RJ, Thai C, Rivera TL, Perez-de Jesus A, Soto-Raices O, Toro-Torres R, Pantojas C (2020) Ixekizumab for patients with non-radiographic axial spondyloarthritis (COAST-X): a randomised, placebocontrolled trial. Lancet 395:53-64

17. Davis JC Jr, Van Der Heijde D, Braun J, Dougados M, Cush J, Clegg DO et al (2003) Enbrel Ankylosing Spondylitis Study Group. Recombinant human tumor necrosis factor receptor (etanercept) for treating ankylosing spondylitis: a randomized, controlled trial. Arthritis Rheum 48:3230-3236

18. Dougados M, van der Heijde D, Sieper J, Braun J, Maksymowych WP, Citera G et al (2014) Symptomatic efficacy of etanercept and its effects on objective signs of inflammation in early nonradiographic axial spondyloarthritis: a multicenter, randomized, double-blind, placebo-controlled trial. Arthritis Rheumatol 66: 2091-2102

19. Molto A, Paternotte S, Claudepierre P, Breban M, Dougados M (2014) Effectiveness of tumor necrosis factor alpha blockers in early axial spondyloarthritis. Arthritis Rheumatol 66:1734-1744

20. Neuenschwander R, Hebeisen M, Micheroli R, Bürki K, Exer P, Niedermann K, Nissen MJ, Scherer A, Ciurea A (2020) Differences between men and women with nonradiographic axial spondyloarthritis: clinical characteristics and treatment effectiveness in a real-life prospective cohort. Arthritis Res Ther 22:233

21. Barkham N, Keen HI, Coates LC, O’Connor P, Hensor E, Fraser $A D$ et al (2009) Clinical and imaging efficacy of infliximab in HLA-B27-positive patients with magnetic resonance imagingdetermined early sacroiliitis. Arthritis Rheum 60:946-954

22. Haibel H, Rudwaleit M, Listing J, Heldmann F, Wong RL, Kupper H, Braun J, Sieper J (2008) Efficacy of adalimumab in the treatment of axial spondylarthritis without radiographically defined sacroiliitis. Arthritis Rheumatol 58:1981-1991

23. Rudwaleit M, Listing J, Brandt J, Braun J, Sieper J (2004) Prediction of a major clinical response (BASDAI 50) to tumour necrosis factor alpha blockers in ankylosing spondylitis. Ann Rheum Dis 63:665-670 
24. De Winter J, de Hooge M, van de Sande M, de Jong H, van Hoeven L, de Konig A, Berg IJ et al (2018) Magnetic resonance imaging of the sacroiliac joints indicating sacroiliitis according to the Assessment of SpondyloArthritis international Society definition in healthy individuals, runners, and women with postpartum back pain. Arthritis Rheumatol 70:1042-1048

25. Weber U, Jurik AG, Zejden A, Larsen E, Jorgensen SH, Rufibach $\mathrm{K}$ et al (2018) Frequency and anatomic distribution of magnetic resonance imaging features in the sacroiliac joints of young athletes: exploring "background noise" toward a data-driven definition of sacroiliitis in early spondyloarthritis. Arthritis Rheumatol 70: 736-745
26. Varkas G, de Hooge M, Renson T, De Mits S, Carron P, Jacques $P$ et al (2018) Effect of mechanical stress on magnetic resonance imaging of the sacroiliac joints: assessment of military recruits by magnetic resonance imaging study. Rheumatol 57:508-513

27. Nguyen C, Bendeddouche I, Sanchez K, Jousse M, Papelard A, Feydy A et al (2010) Assessment of ankylosing spondylitis criteria in patients with chronic low back pain and vertebral endplate Modic I signal changes. J Rheumatol 37:2334-2339

Publisher's note Springer Nature remains neutral with regard to jurisdictional claims in published maps and institutional affiliations. 